\title{
Da substituição das partes litigantes
}

Notas de preleção

1. Considerada em seu aspéto subjetivo, a ação é a faculdade de provocar a atividade jurisdicional do Estado para a apreciação ou a realização de direitos incertos, amea*çados ou contestados.

Facultas exigendi, como diz o professor José Alberto Dos Reis, a ação é o direito á sentença num caso concreto. Ao jus persequendi in juditio corresponde a obrigação jurisdicional do Estado.

A jurisdição civil apresenta-se, pois, como a função por meio da qual o Estado, pelos seus orgãos legitimos, declara a lei aplicavel ao caso particular, providenciando a manutenção ou reintegração do direito lesado.

2. Entre o Estado e os sujeitos de direito, que dele reclamam a decisão do litigio, forma-se uma evidente relação juridica.

De um lado, o direito das partes á emissão da sentença; de outro, a obrigação do Estado de decidir a demanda. 
Eis aí, diz Mario Belavitis, na sua excelente monografia - "L'identificazione della azione", a base de toda a teoria do processo civil, pois só com semelhante conceito se pode "abbracciare tutti $i$ principii giuridici che sono chiamati a garantire l'individuo di fronte allo stesso potere giudiziario dello Stato".

Ideia simples, observa Chiovenda, já entrevista por Hegel e Bethmann Hollweg e, mais tarde, desenvolvida por Bulow e KoHLER, o processo é, indiscutivelmente, a figura externa de uma relação juridica.

3. A relação processual é autonoma, complexa, dinamica e de direito publico.

Autonoma, porque tem vida propria, condições peculiares, independentes da vontade concreta da lei afirmada pelas partes litigantes, isto é, ela se forma e se desenvolve independentemente da relação juridica substancial que o autor e o réo pretendem fazer valer.

Além disso, a relação processual é complexa, pois compreende uma série de direitos e obrigações correlatas, que vão desde a citação inicial até a sentença.

Pertence ao direito publico, porque deriva de normas que regulam uma atividade publica, a atividade jurisdicional do Estado. Entra este na relação, ao lado dos litigantes, não com carater de igualdade, mas como poder publico, armado da coação.

Dinamica, emfim, se diz a relação processual, segundo a feliz expressão de Mortara, porque se acha sempre em movimento e tende, por sua propria natureza, a exaurir-se na sentença judicial.

4. A sentença, em tése, satisfaz a obrigação jurisdicional. Decide o litigio, remóve obstáculos e incertezas, declara a lei aplicavel ao caso concreto, retrotraindo os seus efeitos, pode-se dizer, á data do inicio da causa, tal qual como si fôra nessa ocasião proferida. 
A relação processual deve, pois, manter-se inalteravel, desenvolvendo-se regularmente com os mesmos elementos essenciais, que são os sujeitos, o objéto e a causa de pedir.

Esse, o principio da imutabilidade da ação, a que aludem os modernos processualistas.

5. Com efeito, diz o professor Carnelutti, motivos de relevancia impõem, para o bom exito do processo, a necessidade da imutabilidade dos elementos essenciais da ação.

"Da un lato, la coerenza della azione é senza dubio una condizione perché codesto buono esito si raggiunga; d'altro lato, la libertá del mutanento potrebbe paralizzare nei suoi effetti quel provido freno dell'azione che é la responsabilitá processuale"

Referindo-se especialmente á imutabilidade das partes litigantes no decurso do processo, acrescenta o citado mestre:

"Che pertanto risponda alle esigenze di giustizia un principio della imutabilitá della parte. analogo a quello della imutabilitá del giudice nel corso del processo, mi sembra di potere sicunamente affermare".

6. A lei, porém, admite, em alguns casos, a transformação subjetiva da lide, sucedendo uma pessôa a outra na qualidade de parte.

Essa mudança pode dar-se no sentido formal e no sentido substancial.

Ha mudança formal, quando uma das partes litigantes muda de estado, condição ou representação. Não ha aí propriamente uma substituição, porque a parte continúa em juizo. A mudança de estado, condição ou representação, como observa José Alberto dos Reis, apenas produz efeitos de ordem processual, impondo a pratica de alguns átos, como citações, intimações e outros. 
Por exemplo, o menor, que é parte na causa, torna-se maior. Dá-se ao incapaz um outro tutor ou curador. $\mathrm{Mu}$ da-se o representante da pessôa juridica. Casa-se a parte, tornando-se necessaria, em algumas ações, a presença em juizo do outro conjuge.

7. Dá-se a mudança substancial nos seguintes casos:

a) quando ha sucessão na relação juridica controvertida;

b) quando, independentemente de sucessão, o terceiro vem a juizo afim de substituir uma das partes, excluindo-a da causa.

8. A sucessão pode ser mortis causa e inter vivos.

O falecimento de qualquer das partes litigantes é causa da interrupção da instancia, pois, como diz Pimenta Bueno, céssa com tal fáto a possibilidade de sustentar-se a ação ou a defesa por parte do finado, emquanto não fôr representado ou substituido por seu sucessor.

Cumpre, porém, assinalar que o simples fáto da morte de uma das partes litigantes não faz interromper, por si só, a instancia, impondo a necessidade da substituição processual. Mistér se faz haja prova habil do falecimento, não bastando a méra denuncia do óbito. Validos serão, portanto, todos os átos praticados na causa depois da morte de um dos litigantes, si, a esse tempo, não constava o fáto oficialmente em juizo.

O Codigo de Processo do Estado diz, no art. 220, que a instancia se interrompe pela morte de qualquer das partes, renovando-se pela habilitação dos que ao morto sucedem na causa.

Si os autos, porém, estão conclusos, deverá o juiz proferir o despacho ou sentença, não obstante a denuncia do óbito. As intimações só se farão, no entanto, depois de regularmente renovada a instancia. E' o que manda observar o art. 450 do Codigo. 
9. De regra, segundo conhecido brocardo, heres personam defuncti sustinet.

Ha ações, porém, que não se transmitem aos herdeiros ou sucessores.

Não é possivel, por exemplo, dar-se a substituição processual nas ações relativas a direitos personalissimos, nas que derivam de obrigação de prestar fáto pessoal, nas de mandato, uso, usufruto e outras mais, denominadas pelos escritores ações intransmissiveis ou não hereditárias.

10. Certas ações, no entanto, transmitem-se apenas aos sucessores do credor, não podendo ser continuadas contra os sucessores do devedor.

Estão nesse caso as ações que derivam de fraude do devedor ou as que visam a aplicação de alguma pena.

O Codigo Civil, porém, permite, segundo expressa determinação do art. 1185, a transmissão da ação de revogação da doação por ingratidão do donatário, quando este tenha contestado a lide. Quer dizer, falecendo o donatário, após a contestação da lide, pode esta ser continuada contra os seus herdeiros. Si falecer o doador, podem os herdeiros deste continuar a ação contra o donatário.

11. Por outro lado, certas ações, como as de indenização de danos resultantes do exercicio do patrio poder, do poder marital, da tutela ou da curatela, podem ser continuadas contra os herdeiros do réo, mas não se transmitem aos herdeiros do autor.

12. A successão inter vivos autoriza tambem a substituição da parte litigante.

O sucessor ou cessionario - e aqui empregamos a expressão no sentido amplo, afim de abranger todas as modalidades de transmissão, como sejam a cessão propriamente dita, a compra e venda, a permuta, a doação e outros contratos - o cessionario póde assumir posição na causa, substituindo o cedente. 
13. Friza bem o professor Carnelutti as diferenças que existem entre a sucessão mortis causa e a sucessão inter vivos.

A primeira é involuntária, a segunda, voluntária; aquela supõe, necessariamente, o desaparecimento da parte, ao passo que esta deixa subsistir o sucessor ao lado da pessôa a quem este sucedeu.

Já se vê, pois, que, sendo voluntária, a sucessão inter vivos póde dar-se com o fito exclusivo de prejudicar, de alguma maneira, a parte litigante adversária, pela substituição do cedente pelo terceiro-cessionario.

Oferece, assim, semelhante sucessão perigos e inconvenientes, aos quais sempre se ligou grande importancia, formando-se a respeito, como observa CARnelutTI, uma tradição e uma comunis opinio, que devem ser levadas em conta para o estudo juridico e politico desse assunto.

14. Os romanos não concebiam a sucessão nas obrigações a titulo particular. Vedavam mesmo a cessão ou alienação da res litigiosa. Não cogitavam, porisso, da possibilidade de substituir-se a parte litigante por um terceiro, mediante a sucessão inter-vivos.

Ao passo que admitiam a transmissão da propriedade, proíbiam a cessão das obrigações, porque as consideravam direitos essencialmente relativos, vinculos fortissimos a ligarem determinadas pessôas, que só pela morte se poderiam desatar.

Explicando o assunto, diz Carvalho de Mendonça, na DOUTRINA DAS OBRIGAÇÕES, que “os direitos de crédito tiveram a sua fonte primordial ex-maleficio, no dano causado sem direito. A ação daí decorrente era penae persecutoria, visava a reparação pessoal, vindictam inspirans. Nessas condições, era a obrigação, muito logicamente, intransmissivel átiva ou passivamente".

Abrandou-se mais tarde o rigorismo do velho direito, permitindo-se a cessão de créditos mediante a procuração em causa propria. 
Por uma dessas subtilezas tão comuns no direito romano, o credor transmitia ao procurador em causa propria a ação e não o crédito ou direito.

E o procurador, agia como mandatário mas por su: conta e risco - in rem suam. Dominus litis, como dizem os escritores, apropriava-se da quantia da condenação.

Era por meios, que tais, que os romanos, praticos, mas conservadores, iam conciliando as tradições do passado com as exigencias ou necessidades do momento. Faziam justiça a estas, diz IHERING, mas não rompiam totalmente, seja quanto á fórma, seja quanto á substancia, com os principios tradicionais, ao disciplinarem o comercio juridico.

Posteriormente, a cessão se fazia sem rebuços, transmitindo o cedente ao cessionario a ação util, que criava para este um direito proprio.

15. As legislações modernas consagram o principio da transmissibilidade das obrigações e dos direitos litigiosos. Salvo o caso de algum crédito legal ou convencionalmente incedivel, póde a parte transferir a outrem os seus direitos creditorios.

Pergunta-se, porém: deverá o cessionario, tomada sempre a expressão latu sensu, substituir na causa o cedente, sob pena deste vir a ser considerado parte ilegitima?

16. Para algumas legislações, como a alemã e a austriaca, segundo referencia de Carnelutti, embóra não se negue eficacia material ao negócio feito entre a parte litigante e o terceiro, a substituição processual não se opéra de fáto, porque o cedente continúa na causa. Não já na qualidade de sujeito da relação juridica litigiósa, mas na de representante do cessionário. A sentença extenderá seus efeitos em relação a este.

A lei italiana é omissa a respeito, mas a jurisprudencia de seus tribunais, afirma Chiovenda, tem-se orientado pelas leis alemã e austriaca. 
E assim que, dada a sucessão inter vivos, opéra-se em juizo uma substituição processual sui generis, porque o cedende continúa na causa, agindo em nome proprio, mas para fazer valer o direito do cessionario.

Não é um mandatário, porque age em nome proprio, tanto que, como observa Chiovenda, - " la condanna sará pronunciata contro $o$ in favore dell'alienante, rimasto parte in causa".

A jurisprudencia italiana, porém, tem admitido que o cessionario assuma posição na causa, substituindo de fáto o cedente, desde que haja consentimento da parte contrária.

17. O nosso sistema é diferente.

$O$ cessionario póde substituir o cedente em juizo, assumindo o logar deste na causa.

Diz o art. 465 do Codigo de Processo do Estado:

"A cessão e a subrogação não suspendem a instancia. O cessionario ou subrogado póde proseguir na causa, oferecendo o respetivo titulo e provando a sua identidade, si posta em duvida".

Difere a cessão da subrogação, pois a cessão é a transmissão que o titular faz de seu direito a terceiro, emquanto a subrogação consiste na transmissão de um direito creditorio a terceiro em virtude do pagamento que este faz ao credor por conta do devedor, ou de emprestimo que fez ao devedor para este poder solver a divida, sob a condição de ficar subrogado nos direitos do credor.

A cessão pódie ser a crédito ou a prazo, o que não se dá com a subrogação, em que é essencial o pagamento efetivo ao credor para a extinção da divida e o nascimento de divida nova, como ensina Carvalho de Mendonça.

Interessante notar, ainda, que o direito do cessionario decorre de um contrato equiparavel á venda, ao passo que o direito do subrogado decorre de uma ficção que se originou no pagamento. Na subrogação, acrescenta o citado escritor, 
o devedor só é obrigado a embolsar o subrogado daquilo que este efetivamente deu pela divida, emquanto que o cessionario tem direito a exigir a totalidade do crédito, embóra tenha dispendido menos do que o seu valôr.

18. Como se opéra a substituição?

Deve constar em juizo a cessão ou subrogação, ofenecendo o interessado o respetivo titulo para poder proseguir na causa. Emquanto não se apresentar o terceiro, a causa continúa com o cedente.

19. Si o cessionario não se apresenta em juizo, afim de habilitar-se regularmente, a sentença proferida na causa rextenderá a ele os seus efeitos?

o cessionario, em geral, qual seja o titulo pelo qual adquira a res litigiosa, está sujeito aos efeitos da sentença que fôr proferida contra o cedente.

$O$ adquirente de coisa litigiosa sujeita-se aos riscos da evicção.

Antigamente, as Ordenações proíbiam qualquer contrato sobre coisas litigiosas. Posta a causa em juizo, não podia a parte, sendo réo, "vender, escaimbar ou dar a outrem a coisa litigiosa," e, sendo autor, "ceder a sua ação". Semelhantes convenções eram tidas como inexistentes.

Embóra o Codigo Civil não tenha disciplinado o assunto, ninguem põe em duvida que validos são os contratos que versem sobre direitos ou coisas litigiosas.

$O$ vendedor responderá pela evicção si ocultar ao comprador a litigiosidade da coisa. O comprador, de revês, não poderá demandar pela evicção si sabia que era litigiosa a coisa, salvo estipulação em contrario no contrato.

20. A transformação subjetiva na causa opéra-se, ainda, nos casos de denunciação da lide.

$O$ terceiro vem a juizo afim de substituir o réo.

Com efeito, segundo o art. 73 do Codigo do Processo, o réo, possuidor em nome proprio da coisa demandada, pódc 
denunciar a lide ou chamar á autoria aquele de quem a houve, para que venha defende-la, substituindo-o na causa.

E o chamamento á autoria, intervenção coacta do terceiro, intervenção ad suscipiendum, como diziam os praxistas.

Suspende-se a instancia até haver a citação do chamado á autoria.

Comparecendo o terceiro, com ele proseguirá a causa, ficando o réo exonerado, a não ser que haja algum pedido pelo qual seja pessoalmente obrigado, caso em que deverá continuar em juizo, como litisconsorte passivo.

Si o terceiro, chamado á autoria, não quizer vir a juizo, a causa seguirá á sua revelia, com o primitivo réo.

De qualquer fórma, intervindo na causa, o chamado á autoria a receberá no estado em que estiver.

Dá-se a nomeação á autoria quando o réo é apenas méro detentor ou possuidor diréto da coisa demandada $\mathrm{e}$, para forrar-se aos efeitos da instancia, indica ou nomeia o legitimo proprietario ou possuidor indiréto.

No chamamento á autoria, o réo poderá pedir a citação do terceiro; na nomeação, de revês, segundo o Codigo do Processo, deverá indicar ou nomear o terceiro, legitimo réo na causa.

As diferenças são grandes, como se percebe, pois os efeitos do chamamento e da nomeação á autoria são diversos.

Desde que ha a nomeação, concordando com ela o autor, a causa continuará com o terceiro, ficando o primitivo réo absolvido da instancia e a cargo do autor promover a citação do terceiro.

Caso não surta efieito a nomeação, por não aceita-la o autor, e desde que, no decurso da causa, fique provado que o réo é apenas detentor ou possuidor diréto da coisa litigiosa, claro que o autor deve ser julgado carecedor da ação intentada. 
Si, porém, o nomeado não comparece ou, comparecendo, nega qualidade para estar em juizo, a causa continuará contra ele e o primitivo réo, como litisconsortes.

21. No sistema do Codigo de Processo do Estado, ha ainda um caso de denunciação da lide, a que se refere o art. 77 nestes termos:

"Seja qual fôr a natureza da causa, poderá qualquer das partes requerer, sem suspensão de sua marcha, que se dê ciencia do litigio a terceiros interessados".

Permite o Codigo aos litigantes, em qualquer feito, que do litigio dêm conhecimento a terceiros interessados, por meio de notificação, afim de que venham, querendo, alegar e defender seus direitos na causa.

Dessa intervenção, que é facultativa, não decorre, porém, bem se vê, a substituição processual.

Dr. GABRIEL DE REZENDE FILHO.

Docente-Livre de Teoria e Pratica do Processo Civil e Comercial 